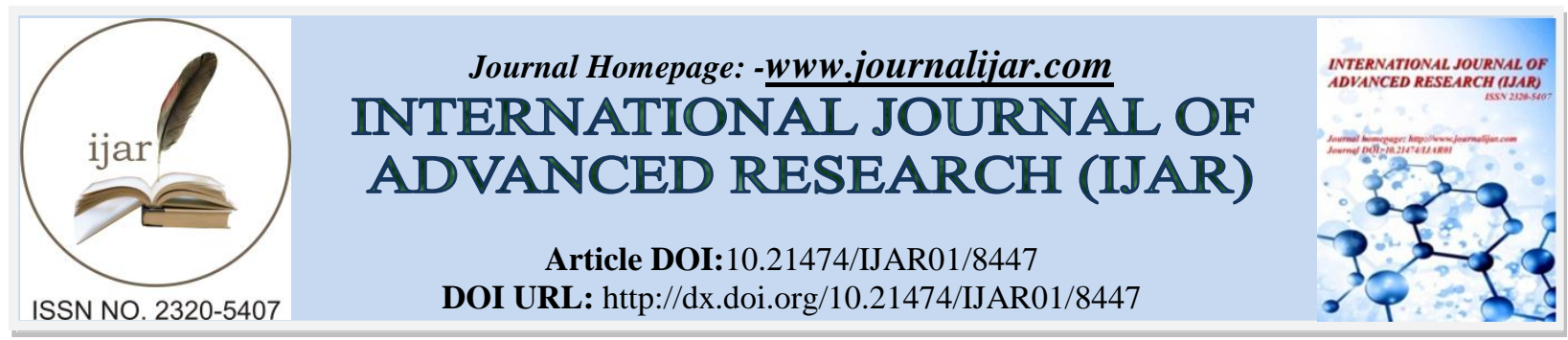

RESEARCH ARTICLE

\title{
FACTORS THAT AFFECT IMPLEMENTATION SPATIAL AND REGION PLANNING IN KECAMATAN KRAMAT JATI - JAKARTA TIMUR.
}

\author{
Syafwandi.
}

Lecturer at the College of Administration Sciences, Menara Siswa, Bogor.

\section{Manuscript Info}

\section{Manuscript History}

Received: 20 November 2018

Final Accepted: 22 December 2018

Published: January 2019

Key words:-

Leadership, local government policies, human resource planning, environmental management, regional planning.

\section{Abstract}

This study aims human resources explain the fachuman resourcesrs that influence the implementation of spatial and regional plans in Kramat Jati Subdistrict, East Jakarta. The fachuman resourcesrs in question are leadership from government officials (sub-district heads), local government policies, human resources planning, environmental management, and community participation. If the three aspects are implemented properly, then it is expected human resources generate community participation in the implementation of regional spatial planning. The samples size are 500 people as respondents who were chosen randomly from the area concerned. The analysis used is the Structural Equation Model (SEM). The results showed that: (1) leadership had a significant positive effect on local government policies; (2) leadership has no significant effect on human resources planning; (3) leadership has a significant positive effect on environmental management: (4) local government policies have a significant positive effect on community participation; (5) human resources planning has no significant effect on community participation; (6) environmental management has a significant positive effect on community participation; and (7) community participation has a significant positive effect on the implementation of spatial and regional plans. The implementation of spatial and regional plans was not in line with expectations, although community participation was quite good. It should be realized that in recruitment of human resources is indeed loaded with nepotism, even though the recruitment system has been very well made.

\section{Introduction:-}

Spatial planning is a human effort in the face of challenges in order to live more properly in the totality of spatial planning that is efficient and effective; and must be designed to be able to predict future problems. The result will be seen in the arrangement of space with no mutual interference, overlapping or briefly visible direction of the development of the city by providing benefits to the majority of city residents. Conversely, if the designer and policy holder are not the right people, it is easy to predict that urban planning is not reflected in a clear concept of direction and purpose. It also tends to harm people who do not have power. In implementation, spatial planning is not well planned, overlapping and evictions are common problems. In a good situation, interdependence, complementary and

Corresponding Author:-Syafwandi.

Address:- Lecturer at the College of Administration Sciences, Menara Siswa, Bogor. 
mutually beneficial should occur. However, in an unfavorable context, improved planning tends to benefit only certain parties, and this continues to be intertwined dialectically.

When first born in the 19th century, it was still a product of planning that could not be said to be utopian was very fantastic. Change becomes unlimited, meaning that spatial planning for the benefit of the environment is not a stage that is only oriented towards the final settlement. There is no correlation with the basic problems that are very influential in planning itself, namely humans.

Can be mentioned by parties that are closely related to spatial planning policy are the Ministry of Home Affairs, the Ministry of Public Works, BAPPENAS. In addition to private institutions, even international institutions such as the Asian Development Bank (ADB) and World Bank (WB) contribute to spatial planning in Indonesia. In 1999, a Keramat Jati District District Spatial Plan was created based on Regional Regulation No. 6 of 1999. The above policy still needs to be listened to, and because its age has reached 6 years; need to be evaluated.

Based on the Kramat Jati District Spatial Plan (1999 - 2005) for housing, it is estimated to be $408.96 \mathrm{Ha}( \pm 30.66 \%)$, it has reached $670 \mathrm{Ha}( \pm 50 \%$ of the total area of 1,334 Ha). This condition according to Ir. Robby to the East Jakarta Sub-district Planning Office, allows it to continue to change with regard to housing needs for the community. A planology expert, Ir Sudrajad Sasmita stated that all this time in spatial planning in its implementation only focused on aspects of space planning and utilization. While the aspect of controlling land use is still low. As a result in the field there was a violation of space utilization

Judging from the aforementioned phenoma, Koswara revealed that problems related to policy implementation often become interesting topics in both industrialized and developing countries. The implementation of wisdom is not just a mechanism for translating the goals of wisdom in the form of routine procedures and techniques. Furthermore, it involves a variety of factors ranging from resources, relationships between organizational units, the level of bureaucracy to certain political groups that may not apply to established applications (Koswara, 2002: 92). Grindle further states that the achievement of outcomes depends on program programs that have been well designed and informed, besides being influenced by the content of pooling and content of implementation (Grindle, 1980: 7, 11). Listening to the phenomena occurring in the field as well as the opinions of several policy experts above, it seems interesting to examine what factors influence the implementation of the Kramat Jati District Spatial Plan in East Jakarta.

\section{Problem Formulation:-}

1. Is there any influence of leadership (sub-district) on local government policy?

2. Is there any influence of leadership on human resource planning?

3. Is there any influences of leadership on environmental management?

4. Is there any influence of Local Government Policy on Community Participation?

5. Is there an effect of Community Resource Planning on Community Participation?

6. Is there any influence of Environmental Management on Community Participation?

7. Is there any influence of community participation on the Implementation of the District Spatial Plan?

\section{Research Methods:-}

The population in this study is the community of Kramat Jati Subdistrict, East Jakarta, which consists of two groups selected purposively; (1) government apparatus respondents (150 people) came from: City Planning Sub-Office and East Jakarta National Defense Agency, Kramat Jati District Office and Village Office located in Kramat Jati Subdistrict; and (2) community member respondents (including youth leaders and community leaders) as many as 350 people. Details of the distribution of respondents are as follows:

Table1 1:-Distribution of Respondents.

\begin{tabular}{|c|l|c|c|}
\hline \multicolumn{3}{|l|}{ Distribution of Respondents in Local Government Apparatus Groups } \\
\hline No & \multicolumn{1}{|c|}{ Institution } & Population(person) & Number of Respondents (person) \\
\hline 1 & $\begin{array}{l}\text { East Jakarta City Planning Sub- } \\
\text { Office }\end{array}$ & 87 & 25 \\
\hline 2 & BPN East Jakarta & 97 & 25 \\
\hline 3 & District Office & 78 & 35 \\
\hline
\end{tabular}




\begin{tabular}{|c|c|c|c|}
\hline 4 & Village Office & 76 & 65 \\
\hline \multicolumn{2}{|c|}{ Sub Total } & 338 & 150 \\
\hline
\end{tabular}

\begin{tabular}{|c|l|c|c|}
\hline \multicolumn{3}{|c|}{ Distribution of Community Group Respondents } \\
\hline No. & \multicolumn{1}{|c|}{ Village } & Population(person) & Number of Respondents (person) \\
\hline 1 & BatuBalekembang & 23.000 & 50 \\
\hline 2 & BatuAmpar & 43.000 & 50 \\
\hline 3 & Kampung Tengah & 37.000 & 50 \\
\hline 4 & Dukuh & 26.000 & 50 \\
\hline 5 & KramatJati & 40.100 & 50 \\
\hline 6 & Cililitan & 65.000 & 50 \\
\hline 7 & Cawang Sub Total & 66.500 & 50 \\
\hline & Total Respondents & 300.600 & 350 \\
\hline & & 500 \\
\hline
\end{tabular}

The conceptual framework of research can be described as follows:-

UU no. 24/1992 concerning Spatial Planning is one of the tools for the develop-ment of the region for the society welfare. However, effectiveness is reduced because there is still an imbalance of perceptions between development ac-tors. On the other hand, people are looking forward to the presence of a clearer, more transparent, legally enforceable spatial plan that is capable of responding to the needs of the community in overcoming the actual agenda in the field.

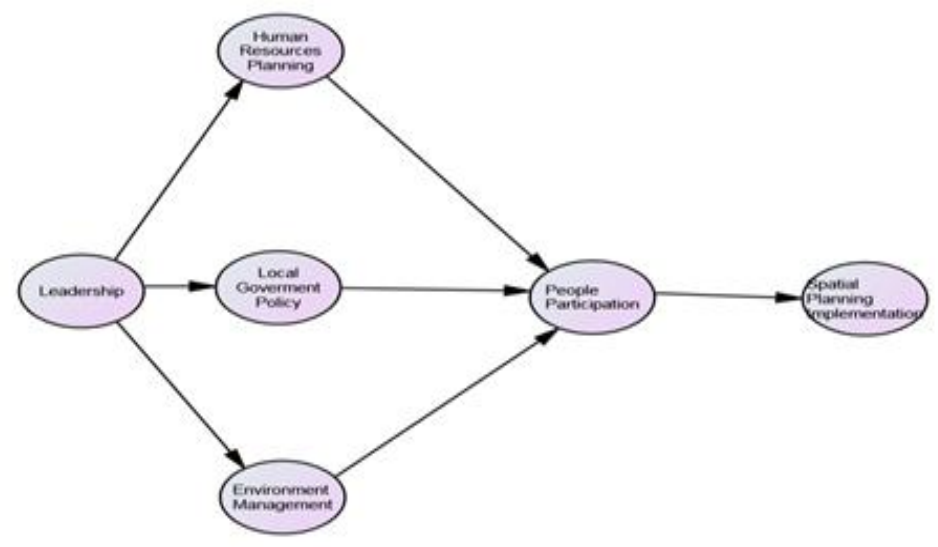

Figure 1:-Conceptual Framework

Leadership (X1) is a matter of relations and influence of leaders and led, leadership can function on the basis of the power of leaders to invite, influence and move other people to do something that is achieving a certain goal (Kartono; 1998: 5). Formal officials in government institutions can determine the quality of human resource planning as employees in their institutions. Steiner (1998: 138) states that human resource planning (X2) is a plan to maintain and enhance the organization's ability to achieve goals, through employee development strategies in the future. To support the implementation of Law No. 24/1992, the sub-district head needs to make a local policy (X3).

It should be noted, that environmental management efforts (X4) are also important for people living in an area. Environmental management is an integrated effort in the use, arrangement, care, supervision, control and development of the environment (Emil Salim, 1989: 166-186). Therefore environmental management can be interpreted as a conscious effort to maintain and improve the quality of the environment so that human needs can be fulfilled as well as possible.

But the most important thing is to prevent the emergence of negative influences on the environment and seek the preservation of natural resources, so that they can be used continuously or continuously from one generation to the next. According to Law No. 23 of 1997 concerning Basic Provisions for the Management of the Environment, said 
environment is a unity of space with all objects, powers, circumstances and living things including human beings and their developing and human behavior.

Spatial and regional plans will be supported by the community in their implementation (Y1), if the community feels it is important to have their participation to accelerate the achievement of the goals of the plan (Y2). (Davis et al; 1997: 106) suggests that participation is mental and emotional of people in a group that encourages them to contribute to group goals and various responsibilities in that goal.

The analytical approach used in this study is the Structural Equation Model (SEM) with the application program AMOS Graphic Version 22.00. Each latent variable is indicated by a reflective indicator and not a formative indicator of three items. Alternative choices for respondents' answers are classified in the form of a $1-5$ Likert interval scale; where $1=$ strongly disagrees with the statement in the item, $3=$ hesitant, and $5=$ strongly agrees to the statement in the item.

\section{Research Results:-}

\section{Descriptive Analysis Results:-}

Descriptive frequency analysis was used to determine the perception of most respondents on items in the questionnaire through the tendency of data frequency. For interval data it is not appropriate to use the average score, for that the approach taken is through the mode score.The results of the descriptive frequency analysis can be summarized in the following Table 2 :

Linciani (2013) also concluded that company size is one of the foundations of earnings management, because the size of the company is an internal condition of the company that reflects the condition of the company. According Richardson (1988) in his research found a significant relationship between information asymmetry shown through the measurement of bid-ask spreads to earnings management. The results showed that the greater the asymmetry of information available to shareholders and management, the higher the level of earnings management accruals that occur. According to Halim, et al (2005) found that firm size has a positive effect on earnings management. Defond (1993) in Veronica and Bachtiar (2003) found that firm size correlated positively with earnings management.

Table 2:-Descriptive Analysis Results.

\begin{tabular}{|c|r|c|c|}
\hline No. & Variable & Mode & Category \\
\hline 1 & Leadership (X1) & 3 & Doubtful \\
\hline 2 & Local Government Policy (X2) & 4 & Good \\
\hline 3 & HR Management (X3) & 2 & Disagree (Bad) \\
\hline 4 & Environmental Management (X4) & 3 & Doubtful \\
\hline 5 & Community Participation (Y1) & 3 & Doubtful \\
\hline 6 & Implementation of Spatial and Regional Planning & 3 & Doubtful \\
& & & \\
\hline
\end{tabular}

Source:-SPSS Printout, processed.

Head of district' leadership is categorized as dubious. This could be because the sub-district head is considered to be less informative to the public, even though the order is clear to employees. Local government policies are considered good, because generally local government policies are always in line with government laws and regulations.Human resource management (employee) is considered bad, can be caused by nepotism, lack of transparency in the career development system among employees, or a reward and punishing system that does not work well. Environmental management is considered doubtful, this can be caused by the commitment of employees who are responsible for it is less sustainable, or even the community itself lacks response to environmental management programs. Community participation was categorized as doubtful, this could be because public trust in the leadership of the subdistrict head was categorized as dubious, plus employees in the sub-district / village were doubtful of their commitment. In addition, the implementation of spatial and territorial plans is categorized as doubtful. These categories have been recorded through descriptive analysis, but have not been able to explain the causal relationship between each variable.

Validity and Reliability Test Results Measurement Indicators:-

Test the validity of measurement indicators can be summarized in the following Table 3 : 
Table 3:-Validity and Reliability Test Results Measurement Indicators.

\begin{tabular}{|c|c|c|c|c|c|}
\hline No. & Indicators & Load Factor & Category & $\mathrm{CR}$ and $\mathrm{VE}$ & Category \\
\hline 1 & X11 & 0,676 & Valid & \multirow{3}{*}{$\begin{array}{l}\mathrm{CR}=0,679 \\
\mathrm{VE}=0,564\end{array}$} & \multirow[t]{3}{*}{ Reliable } \\
\hline 2 & $\mathrm{X} 12$ & 0,662 & Valid & & \\
\hline 3 & $\mathrm{X} 1$ & 0,709 & Valid & & \\
\hline 4 & $\mathrm{X} 21$ & 0,644 & Valid & \multirow{3}{*}{$\begin{array}{l}\mathrm{CR}=0,607 \\
\mathrm{VE}=0,526\end{array}$} & \multirow[t]{3}{*}{ Reliable } \\
\hline 5 & $\mathrm{X} 22$ & 0,612 & Valid & & \\
\hline 6 & $\mathrm{X} 23$ & 0,602 & Valid & & \\
\hline 7 & X31 & 0,600 & Valid & \multirow{3}{*}{$\begin{array}{l}\mathrm{CR}=0,611 \\
\mathrm{VE}=0,525\end{array}$} & \multirow[t]{3}{*}{ Reliable } \\
\hline 8 & X32 & 0,601 & Valid & & \\
\hline 9 & X33 & 0,702 & Valid & & \\
\hline 10 & $\mathrm{X} 41$ & 0,700 & Valid & \multirow{3}{*}{$\begin{array}{l}\mathrm{CR}=0,600 \\
\mathrm{VE}=0,560\end{array}$} & \multirow[t]{3}{*}{ Reliable } \\
\hline 11 & $\mathrm{X} 42$ & 0,673 & Valid & & \\
\hline 12 & $\mathrm{X} 43$ & 0,666 & Valid & & \\
\hline 13 & Y11 & 0,708 & Valid & \multirow{3}{*}{$\begin{array}{l}\mathrm{CR}=0,627 \\
\mathrm{VE}=0,516\end{array}$} & \multirow[t]{3}{*}{ Reliable } \\
\hline 14 & Y12 & 0,675 & Valid & & \\
\hline 15 & Y13 & 0,668 & Valid & & \\
\hline 16 & Y21 & 0,632 & Valid & \multirow{3}{*}{$\begin{array}{l}\mathrm{CR}=0,621 \\
\mathrm{VE}=0,524\end{array}$} & \multirow[t]{3}{*}{ Reliable } \\
\hline 17 & Y22 & 0,609 & Valid & & \\
\hline 18 & Y23 & 0,626 & Valid & & \\
\hline
\end{tabular}

Source:-AMOS Printout, processed.

\section{Results of Structural Equation Analysis}

The estimation results of the structural coefficient with the AMOS program can be displayed as follows:

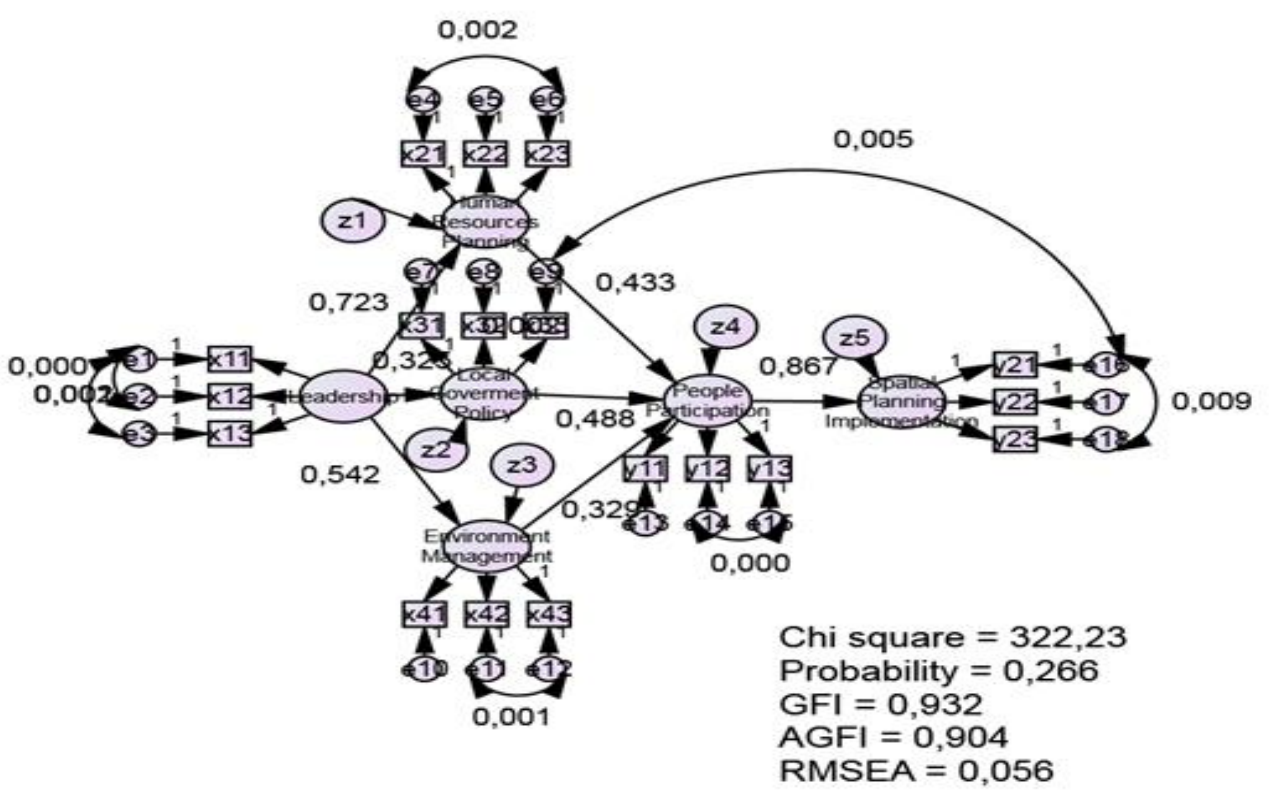

Figure 2:-Explicit Research Model

Results of structural coefficient efficiency tests can be summarized in Table 4:

Table 4:-Test Results of Significance of Structural Coefficien.

\begin{tabular}{cccc} 
Between Variables & Structural Coefficients & Critical Ratio* & Status \\
$\mathrm{X} 1 \rightarrow \mathrm{X} 2$ & 0,732 & 1,994 & Significant \\
$\mathrm{X} 1 \rightarrow \mathrm{X} 3$ & 0,325 & 1,026 & Not Significant \\
$\mathrm{X} 1 \rightarrow \mathrm{X} 4$ & 0,542 & 2,012 & Significant \\
$\mathrm{X} 2 \rightarrow \mathrm{Y} 1$ & 0,433 & 1,999 & Significant \\
\hline
\end{tabular}




\begin{tabular}{rlrc}
\hline $\mathrm{X} 3 \rightarrow \mathrm{Y} 1$ & 0,488 & 1,006 & Not Significant \\
$\mathrm{X} 4 \rightarrow \mathrm{Y} 1$ & 0,329 & 1,978 & Significant \\
$\mathrm{Y} 1 \rightarrow \mathrm{Y} 2$ & 0,867 & 2,032 & Significant \\
\hline
\end{tabular}

Source: AMOS Printout, processed.

Cutoff $=+1.65$ at $\alpha=0.0$.

(1) leadership has a significant positive effect on local government policies; (2) leadership has no significant effect on human resource planning; (3) leadership has a significant positive effect on environmental management: (4) local government policies have a significant positive effect on community participation; (5) human resource planning has no significant effect on community participation; (6) environmental management has a significant positive effect on community participation; and (7) community participation has a significant positive effect on the implementation of spatial and regional plans.

There are no violations in the assumption of SEM: Normality, Outliers and Multicollinearity.

The suitability of the model (goodness of fit model) as a whole meets the criteria as a good model: chi square = 322.23 , relatively large; chi square probability $=0.266>0.05 ;$ GFI $=0.932>0.900 ;$ AGFI $=0.904>0.900$ and RMSEA $=0.056<0.08$.

\section{Discussion:-}

The influence of leadership on local government policies is significantly positive. This means that the better the leadership of the camat as regional leader, the better the policy of the regional government in supporting the Spatial and Regional Plan according to Law No. 24/1992. This means that if the sub-district head has a good understanding of the importance of spatial and regional planning in his area, then surely he will make good local policies to support the success of Law No. 24/1992. The Camat's leadership is the ability of the Camat to control, influence and mobilize others both in the Kecamatan and Kelurahan units to be willing and able to do things according to the expectations and goals of the organization in certain situations. This finding is in accordance with Kartono (1998) 's opinion which states that leaders always try to always make local policies in the corridor of the law as its legal base.

Human resource planning, especially in its development strategy is indicated by the subjective desire of leaders. Tactic likes - dislikes often occur, nepotism, even bribery practices often occur. Public trust in the leadership was also weakened by the trust of sub-district employees towards the leadership. In practice, many employees and officials in this sub-district are not suitable people with regard to capability and commitment, as well as their responsibilities. This finding is contrary to the theory of human resource development from various experts, one of them is Steiner (1998).

The influence of leadership on environmental management is significantly positive. Environmental management in Kramat Jati sub-district which is still categorized as dubious is indeed due to the leadership of the sub-district head which is considered dubious. Inadequate environmental management is also caused by the low commitment of most employees in the respective sub-districts. For example, in creating a District Spatial Plan, the government rarely involves the potential of the local community. Enforcement of compliance with regulations is still weak, so that the environment becomes less well managed. Public awareness of the importance of a comfortable and safe environment is also still doubtful. This becomes an important thing to be immediately improved on all parties, officials, employees and the community itself. From the above phenomenon clearly illustrates the emergence of economic symptoms as a result of the region only pursuing short-term interests in order to calculate regional income to finance regional autonomy. In addition there are also symptoms of neglect of environmental sustainability due to excessive exploitation of natural resources but poorly planned (Sadu, 2002: 13)

The community is totally unaware that they do not understand the results of the spatial plan in their area (Kecamatan). To implement the District Spatial Plan above, it can be predicted that it will encounter obstacles. In this context, the Camat leadership factor that is concerned with the interests of the community should be needed. It should have been since the beginning of the Camat's activities (as the leader in the region) to carry out the action plan movement by involving the community with other relevant stakeholders. So that with a popular leadership figure, the sub-district head can implement the Kramat Jati District Spatial Plan.

Subdistrict head leadership is needed to overcome the problems in the inappropriate environmental management order. For example, the development of green land uses. The Camat should be the leader in his region to act 
immediately to ban the development activities because the activity clearly violates the agreed Spatial Planning. The influence of Local Government Policy is not significant to community participation. Regional Government Policy is a series of actions carried out by the Regional Government through certain stages and procedures as a series of analyzes in order to conduct a study, formulation and policy determination. Whereas community participation is defined as the physical and mental involvement of the community in both individual and collective utilization. However, in compiling local government policies, the Camat rarely engages the community in the policy-making process as the main stakeholder. The community does not know the policy objectives of the local government, because rarely or no intensive socialization is carried out to motivate community participation.

The effect of human resource planning is not significant on community participation. The meaning that can be drawn from the above analysis is that community participation will increase to implement the Regional Spatial Plan if the government institution conducts HR planning in its environment professionally so that the apparatus who work are officers who are disciplined, skilled and caring. The community feels underserved and makes them not motivated to implement Spatial Planning. From observations in several research areas it turned out that the relevant Dinas officers did not know that there were products of the Regional Spatial Plan. This shows the shallowness of their knowledge of the Regional Spatial Plan which is more comprehensive. This is in accordance with the opinion of Suyarto (1985).

Effect of environmental management on community participation in implementing spatial and regional plans, significant and positive. This indicates that community motivation will increase to implement the spatial plan if the local government institutions carry out environmental management in their territories in accordance with the programs that have been planned and set together. If the environmental management violates the Regional Spatial Plan that has been determined, it will impact community participation will decline. Departing from the above phenomenon, perhaps the incident of settlement construction in the area of Condet Balekambang Village which is a cultural heritage area (according to DKI Governor Decree No. 7903 / a / 30/1975) can be used as an example of the helplessness of local regional leaders and the community in implementing the Regional Spatial Plan appropriately. The location of the area is actually clear for the preservation of fruit cultivation and at the same time protecting the Betawi tribe from the insistence of immigrants. The immigrants supported by the regional apparatus did not care, they settled and tried in the environment in the region, and the result was quite pronounced, namely: currently the area which is the Ciliwung riverbank area is disturbed, so that lately the area has often been flooded. From the legal aspect, it is clear that the builders have violated Regional Regulation No. 6/1999 concerning Spatial Planning and Law No. 34 of 2005 concerning regional autonomy.

Community participation in the implementation of spatial and regional plans is quite large (0.867). This means that the implementation of regional spatial planning will be achieved if all stages (preparation of spatial plans, utilization and control) are jointly prepared and involve the community, supported by other stakeholders. This finding is in accordance with Davis's opinion (1967) which states that each party understands the role and adheres to a predetermined plan, so that later on the government will act as a facilitator, on the contrary the community becomes the main actor and beneficiary of the development. If the opposite happens, the community is only used as an object of a spatial policy, and even in its implementation it is often abandoned, then what happens is a violation of the planned spatial layout. As an example of the application of Perpres No. 36/2005 concerning land acquisition for the implementation of development in the public interest. But because it seemed oriented to the interests of the state, not for the benefit of the people, this was marked by the mechanism of its formation which only stated the BPN as the compiler, while the discussions were carried out by the Governors throughout Indonesia for its endorsement. So to apply in the field, there are obstacles. Decision makers may forget that in order to succeed in a policy that relates to the rights of the people, it is best to include the people associated with the policy. But what happened was that the government immediately issued Perpres No. 36/2005. Spontaneously, the regulation received strong rejection from various elements of society, the regulation was considered to rob the people's land rights.

\section{Conclusion:-}

1. Based on the results of research and discussion, the following conclusions can be expressed:

2. Leadership has a significant positive effect on local government policies;

3. Leadership has no significant effect on HR planning;

4. Leadership has a significant positive effect on environmental management:

5. Local government policies have a significant positive effect on community participation;

6. Human resource planning has no significant effect on community participation;

7. Environmental management has a significant positive effect on community participation; and 
8. Community participation has a significant positive effect on the implementation of spatial and regional plans.

\section{Suggestions:-}

Some suggestions that can be submitted are as follows:-

1. From the results of the study indicate that the leadership variables influence the policy variables of the local

2. government, environmental management and implementation of spatial plans for the activities of the District area.

3. The influence of these variables is positive, even though to further improve the implementation of the spatial plan of

4. the sub-district area, it is necessary to strive for steps to increase the leadership factors as follows:

5. Increasing the capacity and capability of each individual as regional manager through formal and informal education.

6. Providing clearer governmental authority at each level of government.

7. Implement situational leadership models and firmly discipline in carrying out their daily tasks.

8. Provision of adequate operational funds to support the implementation of tasks.

9. Carrying out intellectual grading both formally and informally.

10. Local government policies need to be improved by, among others:

11. Policies that are oriented towards the interests of the community.

12. Local government policies that will be made must not conflict with higher regulations.

13. Local government policies made must be based on the dynamics of community change.

14. Government policies made in improving the effectiveness and efficiency of services to the community.

15. Human resource planning is also a factor that needs to be improved through the following efforts:

16. Applying the right man in the right place model in the work environment of the district area institutions.

17. Providing sanctions and appreciation to the authorities in carrying out their duties, especially in the service of the community.

18. Improving the quality of Human Resources by including apparatus to attend school at S1, S2, S3 level

19. Include Human Resources in intellectual and formal up-grading.

20. Environmental management, needs to be improved by means of among others:

21. Memorizing activists or the community in various environmental management activities.

22. Include officials or the community in activities to improve knowledge and care in environmental management, for example through training, and so on.

23. Sensitive to the issue of the environment around the region.

24. Community participation also needs to be improved in the following ways:

25. Communities need to be empowered as partners in every development activity in their region.

26. Communities need to increase their involvement in voluntary and emotional development (without coercion).

27. The community needs to participate in activities related to the spatial layout of the District.

28. If the government intends to improve the quality of the implementation of the District Spatial Plan, it should begin with motivating the community to increase their participation, by improving the quality of local government, HR planning, and Environmental Management.

29. In implementing the plan there will be a reciprocal relationship with the decision making process during planning. It is also recommended that during the planning process pay attention to the aspirations of the community.

30. The realization of the District Spatial Plan implementation in Kramat Jati District, East Jakarta is influenced by many factors. Therefore, for researchers who are interested in conducting research on similar problems, it is advisable to examine other factors not analyzed in this study such as law enforcement and socio-economic.

\section{References:-}

1. Cheema, Shabbir, G., and Dennis A. Rondinelli, 1983. Decentralization and Development Policy Implementation in Developing Countries Beverly Hills, CA.

2. Davis, Keith, 1997. Human Relation at Work. New York: Mc Graw-Hill.

3. Dan Newstrom, James. 1990. Perilaku dalam Organisasi, terjemahan, A. Dharma. Jakarta: Erlangga.

4. Diggs, F.W.1970. Frontiers of administration Development system and Human Resources Approach. Auckland: Mc Graw-Hill International Book Company.

5. Dunn, Wiliam N., 1981, An Introduction to Public Policy Analysis, Englewood cliffs,prentice hall, inc ( $3^{\text {rd }}$. ed). 
6. Duseldorp, D.1981. Participation in Planned Development Influenced by Government of Developing Countries at Local Level in Rural Areas. Wageninge: Agricultural University.

7. Grindle, Marilee S., 1980. Politic and Policy Implementation in the Third World, New York: Princeton University Press.

8. Gultom, R.M.S. 1985. Partisipasi Masyarakat Dalam Pembangunan. Salatiga Universitas Kristen Satya Wacana.

9. Hamidjoyo, SS. 1997. Partisipasi Masyarakat Dalam Pembangunan. Bandung Unpad.

10. Kertapradja, Koswara. 2002. Otonomi Daerah, Jakarta; PT. Candi Cipta Paramuda.

11. LG, White. 1982. Managing Development in the Third World, Colorado Westviuw Presas.

12. Ndraha, Taliziduhu, 1985, Research Metodologi Penelitian,Jakarta, Bina Aksara.

13. Ndraha, Taliziduhu. 1997. Pengantar Teori Pengembangan Sumber Daya Manusia. Jakarta Rineka Cipta.

14. Pamudji, S. 1995, Kepemimpinan Pemerintah di Indonesia, Jakarta Bumi Aksara

15. Painudji, S, 1995, Kepemimpinan Pemerintahan di Indonesia, Jakarta, Bumi Aksara.

16. Rasyid Muhammad Ryas, 1997, Makna Pemerintahan, Tinjauan dari Segi Etika dan Kepemimpinan, Jakarta, Yarsif Watampone.

17. Rencana tata Ruang Wilayah Kecamatan Kramat Jati Tahun 1999-2005

18. Salim Emil. 1989. Pembangunan Berwawasan Lingkungan. Jakarta: LPES-UI.

19. Sastropoetro, S.R A. 1995. Partisipasi Komunikasi, dan Disiplin dalam Pembangunan Nasional. Bandung: Alumni.

20. Sewel, w.R.D \& Coppoc, JT. 1977. Public Participation in Planning, London, John. Willy and Son Book Company.

21. Soemarwoto, Otto. 1991. Ekologi Lingkungan Hidup dan Pembangunan. Jakarta Jembatan.

22. Sumanto 1995, Metodologi Penelitian Sosial dan Pendidikan, Yogyakarta Andi offset

23. Suradinata, Ermaya, 1996, Manajemen Pemerintalian dan otonomi daerah, Bandung : Ramadan.

24. Suradinata, Ermaya, 1998, Manajemen Pemerintalian dan otonomi daerah, Bandung : Ramadan Citra Grafika.

25. Suradinata, Ermaya 1998, Manajemen Pemerintahan dan otonomi Daerah, Bandung: Ramadan.

26. Suyarto, Djoko. Beberapa Pengertian tentang Perencanaan Fisik Jakarta: 1985

27. Tennenbaun, Arnold, \& Han, 1998. Partisipation in Union Locals. New York Peterson and Company.

28. Thoha, Miftah 2001, Kepemimpinan dalam Manajemen, Jakarta: PT Raja Grafindo Persada.

29. Thoha, Miftah, 1991, Dimensi-dimensi Prima Adninistrasi Negara, Yogyakarta: Fisipol UGM.

30. Umar, Husein, 1999, Riset Sumber Daya Manusia dalam Organisasi, Jakarta: PT. Gramedia Pustaka Utama.

31. Undang-Undang Republik Indonesia No. 24 Tahun 1992 Tentang Penataan Ruang.

32. Undang-Undang Republik Indonesia Nomor 22 Tahun 1999 tentang Pemerintahan Daerah.

33. Undang-Undang Republik Indonesia Nomor 34 Tahun 1999 Tentang Pemerintahan Propinsi Daerah Khusus Ibukota Jakarta.

34. Undang-Undang Republik Indonesia Nomo 3/2005 Tentang Otonomi Daerah

35. Watts, Kenneth, 1985. Survei Tata Kota DK, Bandung. 